\section{НАСУШНИ БИТАК САВРЕМЕНОГ СРПСКОГ ПЕСНИШТВА НАКОН ЕЛИОТА И ВАЛЕРИЈА}

Филозофски факултет

Универзитет у Новом Саду

\author{
(Слободан Владушић, Орфеј и зайушач:

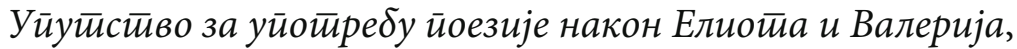 \\ Нови Сад: Академска књига, 2018, 117 стр)
}

Посве ретку и вредну појаву на српском књижевном небу чини моменат када једна личност истовремено закуца на двоја врата истоветног литерарног дома - врата есејистике и прозе. У јесен 2018. године из штампе су изашла два наслова Слободана Владушића: роман Велики јуриш и књига научних есеја о књижевности Орфеј и зайушач. Професор Владушић објединио је своје раније утемељено обраћање ужој и широј публици - проучаваоцима књижевности и читаоцима романа, којих је данас, по свему судећи, највише.

Књижевноисторијска и књижевнотеоријска мисао Слободана Владушића разграната је кроз књиге есеја, критике и теоријске ра-

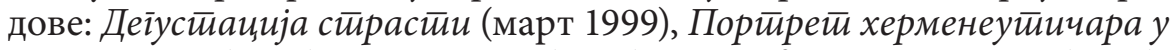
йранзицији (2007), На йромаји (2007), Ко је убио мрииву gрайу (2009), Црњански меіалойолис (2011, 2012), Кочарка йо је Парииизан (2016), Книжевности и коментиари (2017). Од прве књиге, штампане уочи НАТО бомбардовања Савезне Републике Југославије, до последње, написане у ери геополитичких превирања и надјачавања, Владушић проговара о насушној борби и непристајању појединца на културну опсаду. Када пише о слободи коју живе јунаци прозе или лирски субјекти поезије (некада су то и сами песници), аутор размишља о актуелном историјском тренутку, јасно говорећи и о перманентном ратном стању у српској књижевности и култури.

Наслов књиге Орфеј и зайушач наизглед је гротескни спој античког распеваног Аргонаута и запушача, тј. поклопца за флашу. У наслову књиге есеја о савременом српском песништву Орфеј има своје место, али шта ту тражи запушач - је ли то метафора или симбол? Могући одговор на питање крије се у тексту „Запушачи“, који је аутор објавио на блогу „Нови полис“. Текст је настао на трагу Попине песме „Земаљско сазвежђе“, у којој песнички субјекат уочава запушаче утиснуте у земљу испред продавнице, купује пиво и придружује се радницима који пију, а затим утискује свој запушач-звез- 
ду у сазвежђе осталих запушача. У Владушићевом тексту запушач је симболички представљен као детаљ у мозаику једног имагинативног, али ипак постојећег света. Реч је о запушачима са флаша пива која се не производе. За разлику од Попе, Владушић говори о лименкама без запушача, тј. о ишчезавајућим предметима, који се рециклирају у целости. Насупрот свепрождирућем времену и дисконтинуитету стоји мисао којом текст „Запушачи“ поентира: „Поезија се не рециклира. Ни запушачи. Ни људи.“ На овај начин већ у наслову је обухваћена Орфејева вечна песма осветљена метафором из света данашњице, из „оскудног времена“ свеопште рециклаже, потрошње и хиперинфлације. Одговор на питање појаве запушача у наслову читалац ће пронаћи и у последњем есеју у овој књизи.

Одмах испод наслова стоји још једно „упутство“. У поднаслову Книжевностии и коменйара јесте „Упутство за оружану побуну“ Гија Дебора - француског писца и филозофа, аутора књиге Друшйво сиекийакла и хроничара побуне савремених робова. Орфеј u зайушач садржи „Упутство за употребу поезије након Елиота и Валерија“, што алудира на прво упутство, где је отпор наметнутој норми читања након Елиотовог одабира традиције и Валеријевог отклона од ње својеврсни императив тумачења универзалне природе поезије. Аутор ће дати и одговор на питање зашто је одабрао Елиота и Валерија као симболе двеју утицајних струја модерне европске теорије књижевности: „Иако су обе ове поетичке линије полазиле од момента деперсонализације песничког чина, њихови путеви су се разилазили. Никада до краја појмљене као стриктне поетичке опозиције, елиотовски концепт традиције и валеријевско довршавање бодлеровско-малармеовске линије француског симболизма, ипак су били у стању тихог поетичког рата“ (40). Ово су аналитички темељи на којима Слободан Владушић гради ткиво своје књиге.

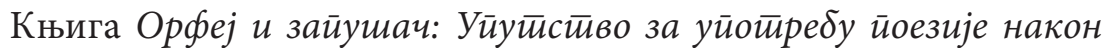
Елиойа и Валерија садржи седам огледа о поезији савремених српских песника. Рукавци Владушићевог херменеутичког захвата протежу се од романтизма и класицизма до модернистичке и постмодернистичке поетике - епохе савременог српског песништва.

У есеју „Од славуја до кокошке (обичне, не огњене)“ указано је на употребу симбола у служби идентификације песничког субјекта. Окретање природи и симболима који долазе из њене сфере аутор анализира на примерима поетике романтичара и савремених песника. Класицистички идеал locus amoenus и романтичарска тежња бесконачности улазе у песништво посредством птица: тако се издвајају славуј, птица звучања; орао, краљ неба и епски првак, али и албатрос и лабуд, силом уземљене птице; све до кокошке, али не огњене, какву срећемо у поезији Новице Тадића. Када говори о разградњи и деконструкцији романтичарских митова, Слободан Владушић указује на поетику Шарла Бодлера: „Ако је романтичарски 
песник путем одређених мотива желео да испуни своју симболичку фантазију која га је преображавала у бога (који је вечан и који мртво претвара у живо), онда је Бодлер у својим јасним, алегоријски структурираним песмама, желео да укаже на немогућност макар и симболичког испуњавања тих романтичарских фантазија о свемоћи песника“ (12). Аутор даље прати својеврсну орнитопоетичку генезу песништва, у оквиру које су птице и њихов уплив у предметни свет поезије маркери померања епоха и естетичких погледа на окружење. У бестежинском стању Раичковићевих ласти из песме „Песници“ препозната је „дехероизација романтичарског песника“ настала „променом саме 'форме' песника: величина песника (оваплоћена величином орла и албатроса) сада је умањена на ниво ласте, која [...] сугерише нешто безазлено и наивно, нешто невидљиво, али и неухватљиво“ (15). Осим дехероизованих птица, у савеменом српском песништву Владушић уочава и птице лишене значења Попина „Патка“ или „антипоетичке и антихералдичке птице“ попут Павловићеве и Попине кокошке. Уплив птица лишених идеалног и узвишеног обележја у песништво приказани су кроз осветљавање система тзв. депоетизованог, новог простора песме: „Депоетизована поезија која врши насиље над дотадашњом поезијом, тако истовремено креира и ново разумевање опозиције обично / необично као и нови систем вредности који омогућује да нешто може бити виђено у поезији“ (19). Задатак савремене поезије да у себе апсорбује оно што јој је далеко и наизглед недокучиво остварен је депоетизацијом, отклоном од самог певања.

Оглед „Стеван Раичковић, романтичарска воља, модернистичка нужност“ садржи две целине. У првој се књижевнотеоријским разматрањима указује на разноликост романтизма, схваћеног као стваралачка интенција и интуиција, а не као уметничка епоха. Нагласак је стављен на разјашњење феномена перманентног отклона од романтичарске традиције у модерном песништву, чиме се не напушта једно песничко усмерење, већ се оно даље конструише и оплемењује новим поетичким наносима. У есеју је указано на разлику између романтизма као епохе и неоромантичарских поетичких интенција модерних песника. Ову песничку диспаратност аутор види као игру прожимања осамљивања и усамљености песничког субјекта: „Крах романтизма као стилске формације, као поетике, настаје када модерност понуди субјекту да се одрекне лица како би заузврат његово тело било испуњено уживањима, која му лице не би могло пружити“ [...]. Па ипак, разликовање романтичарске поетике и романтичарских интенција, омогућује нам да схватимо како је могуће да се у песничкој традицији појављују неоромантичарске песничке творевине...“ (31). Владушић у другом делу есеја осветљава стражиловску линију Раичковићевог песништва, односно круг песама о природи насталих из судара романтичарске интенције да се приклони приро- 
ди (као Апсолуту) и модерне самоосвешћености која лирког субјекта оставља у ситуацији немогућег духовног уврежавања са Апсолутом.

Есеј „Третман мита у поезији Миодрага Павловића, Љубомира Симовића и Бранка Миљковића“ указује на присуство елиотовског код Валерија и валеријевског код Елиота, из чега произлази ауторово тумачење односа према миту у поезији. Елиотовски осећај за историју/традицију, прожет свешћу о савременом, допуњен је валеријевским аутоматизмом и аудитивном имагинацијом. Резултат овог прожимања јесте јединствен поетички простор, у којем су се обрели савремени српски песници. Павловићев однос према миту представљен је као својеврсна поетичка негација: „Креирајући антислике митова, песнички субјект их не укида, већ их (парадоксално) модернизује и релативизује. [У питању је] хуманистичко настојање да се негирање мита одржи у животу на начин на који је у модерним временима то једино могуће: негацијом, која одржава у хоризонту оно што се негира“ (45). За разлику од негације мита Миодрага Павловића, у Симовићевој поезији аутор уочава деградацију мита, који је „деформисан, што значи да постаје жртва гротеске“ (47). Владушић сматра да је за мит код Симовића кључан раскид са историјом и отклон од елиотовског доживљаја традиције, чији је циљ утемељење предметног света песме у сфери изван културно-историјског памћења. Поезију Бранка Миљковића аутор пак смешта у валеријевски поетички круг. Миљковићев однос према миту осветљен је из угла односа песме и певања, о којем говори Новица Петковић: „Мит код Миљковића постаје једна џиновска метафора песме, како би се путем те метафоре извела операција мишљења певања, односно претварања поезије у поетику“ (52). На тај начин комуникација са митом изједначена је са трагањем за певањем о песми, о поезији валеријевски чистој и рафинираној. Код сва три песника одос према миту јесте плодотворно отварање поетике и њено даље гранање у наизглед неосвојиве просторе песме и певања.

У есеју „Новица Тадић и Шарл Бодлер“ дата је компаративна анализа поетика два песника, заснована на мотиву града. Бодлерова разградња романтичарске визије града (света) код Тадића ствара потребу за продужетком овог поступка и његовом применом на саму Бодлерову поезију: „Наиме, на исти начин на који је Бодлер тематизацијом костура празних очних дупљи у песми 'Мртвачки плес' разоткрио романтичарску визију мртве драге као пуку илузију, тако ће Тадић, деформисаним читањем Бодлерове слике града, раскинути са естетском визијом града француског песника“ (57). Према Владушићу, Тадић разграђује симболизам онако како је симболизам разграђивао романтизам и ствара „машину за уништавање бодлеровских фантазми“ (59). Једна од њих је Бодлеров песнички субјект, који је код српског песника огољен и лишен моћи да издвојен из масе посматра свет са безбедне дистанце. Цвейови зла у лирици Новице 
Тадића почињу да горе, добијају своју огњену, инферналну особеност, али и капацитет за стварање савременог поетичког језгра.

„Улога ћутања у аутопоетичким фрагментима Васка Попе“ је први од два есеја у овој књизи посвећена великом српском песнику. Као и у претходним разматрањима, и овде аутор разоткрива елиотовску природу поетике Васка Попе, односно елементе осећања за историју које се у песништву након романтизма узима као поетичка константа и нужност. Владушић у Попиној поезији уочава хајдегеровски однос према језику, где је уместо филозофског брбљања постављена магла од мртвих речи које заклањају и штите пут до есенције језичког смисла и значења. Попа уздиже речи на пиједестал и чува језичку „кућу бивствовања“ помоћу бдења, тј. усмерености на речи и њихову животворност: „Бдење упућује на усредсређеност на речи, на пажњу која им се придаје и која тако подигнута уцеловљује песника, јер је цело његово биће преко бдења упућено ка живим речима“ (75). Слободан Владушић књижевноисторијски доследно сецира аутопоетичке фрагменте Васка Попе и из њих издваја редове који својим одсуством указују на речи свеприсутне и обогаћене семантичком дубином - на шапат попут молитвеног. Из ћутања проговара се и мртвим речима, речима које се говоре неизговарањем, као у поетским молитвама, каква је песма „Руке бола“ Стевана Раичковића.

Други текст о улози ћутања у поезији јесте „Елементи десакрализације поезије у Случајним мемоарима Стевана Раичковића“. Проблем десакрализације, или лишавања песничког чина вере у поезију, образложен је на примеру Раичковићеве поеме Случајни мемоари. Аутор одређује најпре границу аутосакрализације поезије, која „подразумева ту разлику два језика, тако што се сам песнички чин поставља између свести о несавршености језика и жеље за савршеним језиком“ (83), а затим шири херменеутичку мрежу како би указао на одлике десакрализације поезије: „[...] прва важна одлика десакрализације поезије јесте напуштање једног изнуйра постављеног филозофског питања 'шта је поезија', повезаног са питањем естетске вредности ('шта је велика поезија')“ (86). Уместо овог питања, десакрализација поезије бави се текстом и питањем да ли је он поезија или не. Измештањем поезије у простор ван уметности, према Владушићевом ставу, отвара се свет стварања нове књижевне форме у једној новој поетичкој закономерности: „[...] Случајни мемоари теже да замрзну процес претакања животне грађе у уметничко дело у једној тачки, управо зато што настоје да десакрализују уметност, да је преобразе у нешто друго од естетског предмета, што би живот постао да се процес претакања у књижевну форму довршио до краја“" (95-96).

У есеју „Промена концепта поезије у позним збиркама Васка Попе“ Слободан Владушић скреће пажњу на мање познату, „прећутану“ поезију српског песника из последње три поетске књиге. Реч 
је о радикалној промени чина певања, која „задире у сам концепт песништва“ (100) и враћа биографију писца у фокус поетике. Позне Попине песме које је књижевна критика заобилазила, вероватно због уплива песникове биографије, Владушић чита као поезију реперсонализације: „Реперсонализација песничког чина, након целог једног века у коме је деперсонализација схватана као песнички аксиом, успоставља нови концепт поезије, а не поетичку мену унутар истог концепта деперсонализоване поезије“ (101).

Комад песникове поетике симболички је одрезан збирком Рез од дотадашњег стварања и саткан од пресне материје тј. Живоі меса, јер садржи објективизацију Попиног животног искуства, које као такво има могућност да уплива у поетичку нит, да се уоквири у трајању, не нарушавајући концепт модерне поезије и не тонући у анахрони романтичарски занос: „.. реперсонализована песма има у себи нечег сировог, живог, непрерађеног: она се перципира као нешто недовршено, али не у смислу фрагментарости, већ у смислу недорађености песничког материјала“ (103). Према ауторовом ставу, за разлику од романтизма који има задатак да осами песника како би отуђено песничко ја певало из те перспективе, Попина модерна поезија остварује сусрет песничког и непесничког, поетике и живота (личности). Оваква реперсонализована књижевност јесте „канал за размену искуства“ (106) између песникове биографије и библиографије, чиме је обезбеђено присуство личности у литератури.

Збирка научних есеја Слободана Владушића Орфеј и зайущач:

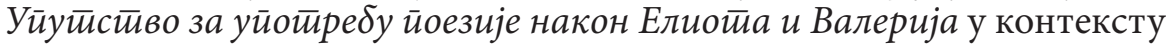
светске лирске и књижевнотеоријске речи исцртава путоказе новим истраживачима савременог српског песништва у правцу отвореног тумачења које дозвољава интензивнију живост личности песника и критичара; као и слободу свеприсуства ставова теорије и поштенију комуникацију са њеним исходиштима у свету науке о књижевности. 